\title{
Deregulation of the SRC Family Tyrosine Kinases in Gastric Carcinogenesis in Non-human Primates
}

\author{
JOANA DE FÁTIMA FERREIRA BORGES DA COSTA ${ }^{1 *}$, CARLA DE CASTRO SANT' ANNA ${ }^{2,3 *}$, \\ JOSÉ AUGUSTO PEREIRA CARNEIRO MUNIZ ${ }^{4}$, CARLOS ALBERTO MACHADO DA ROCHA ${ }^{5}$, \\ LETÍCIA MARTINS LAMARÃO ${ }^{6}$, CAROLINE DE FÁTIMA AQUINO MOREIRA NUNES ${ }^{1,7}$, \\ PAULO PIMENTEL DE ASSUMPÇÃO ${ }^{3}$ and ROMMEL RODRIGUEZ BURBANO ${ }^{1,2}$

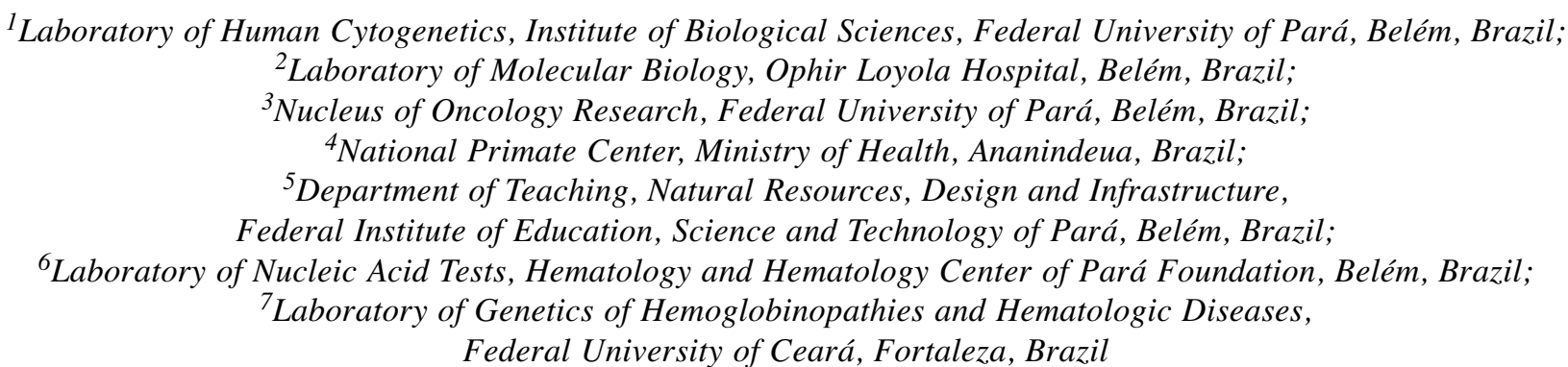

\begin{abstract}
Background/Aim: The evolution of gastric carcinogenesis remains largely unknown, as the regulatory mechanisms involved in the aggressiveness of gastric cancer are still poorly understood. Kinases are downstream modulators and effectors of various cell signaling cascades and play key roles in the development of neoplastic diseases. The objective of this study was to evaluate the expression of genes and proteins of the SRC family, including FYN, YES, $B L K, F G R, L Y N$ and $S R C$, in a model of intestinal gastric carcinogenesis generated by treating Cebus apella, a New World non-human primate, with $N$-methyl nitrosourea (MNU). Materials and Methods: mRNA expression of genes was measured by real-time reverse transcription quantitative $P C R(R T-q P C R)$ and protein expression was measured by western blotting in six Cebus apella treated with N-methylnitrosourea (MNU) for about 2.5 years. Results: Elevated $m R N A$ and protein expression mainly of the SRC and LYN kinases was observed. Their expression was gradually increasing as non-atrophic gastritis was evolving to gastric
\end{abstract}

\footnotetext{
*These Authors have contributed equally to this work.

Correspondence to: Carla de Castro Sant' Anna, Laboratory of Molecular Biology, Ophir Loyola Hospital, Av. Governador Magalhães Barata 992, 66063-240 Belém, Pará, Brazil. Tel: +55 91980118880,e-mail: santannacarla@yahoo.com.br
}

Key Words: SRC family, kinase, gastric cancer, gene expression, protein expression. cancer. Conclusion: SRC family kinases play a key role in tumor progression and metastasis and may be a promising target for the treatment of gastric cancer.

Gastric cancer (GC) is the leading cause of cancer-related mortality worldwide and its incidence continues to increase in both developed and developing countries (1). Currently, the mechanisms underlying GC initiation, progression and metastasis are not fully understood (2). Most GC patients are diagnosed with advanced diseases, resulting in poor prognosis, thus highlighting the importance of identifying useful biomarkers (3). $c$-SRC was the first oncogene discovered in the group of kinases, and its protein product belongs to the family of non-receptor tyrosine kinases (SFKs), which are among the most studied proteins (4-6). SFKs are pleiotropic kinases involved in several cellular events, and their overexpression may contribute to different aspects of tumor development (6). Increased expression of $\mathrm{c}$-Src has been observed in a variety of tumors, including GC (7-9). Of all the kinases of the SRC family - which also include FYN, YES, BLK, YRK, FGR, HCK, LCK and LYN, $\mathrm{c}$-SRC is the prototype member and the one most frequently involved in cancer (6).

Compared to rodents, non-human primates (PSN) are more similar to humans in regard to their genetic evolution, anatomy, physiology, biochemistry and organic systems (10), and, thus, provide a useful model for studies on carcinogenesis $(11,12)$.

The aim of this study was to evaluate the mRNA and protein expression of SCR, LYN, BLK, Yes, FYN and FGR 
Table I. Mean and standard deviation of BLK, FGR, FYN, LYN, SRC and YES mRNA expression in different clinical profiles of MNU-treated animal biopsies.

\begin{tabular}{lcccccccc}
\hline Treatment & Histology & $\begin{array}{c}\text { No. of } \\
\text { animals }\end{array}$ & $\begin{array}{c}B L K \\
\text { Mean } \pm \text { SD }\end{array}$ & $\begin{array}{c}F G R \\
\text { Mean } \pm \text { SD }\end{array}$ & $\begin{array}{c}F Y N \\
\text { Mean } \pm \text { SD }\end{array}$ & $\begin{array}{c}L Y N \\
\text { Mean } \pm \text { SD }\end{array}$ & $\begin{array}{c}\text { SRC } \\
\text { Mean } \pm \text { SD }\end{array}$ & $\begin{array}{c}Y E S \\
\text { Mean } \pm \text { SD }\end{array}$ \\
\hline Baseline & Normal mucosa & 6 & 1 & 1 & 1 & 1 & 1 \\
MNU/90th day & Non-atrophic gastritis & 6 & $1,165 \pm 0,094$ & $1,060 \pm 0,053$ & $0,96 \pm 0,098$ & $1,051 \pm 0,104$ & $1,139 \pm 0,101$ & $1,082 \pm 0,052$ \\
MNU/120th day & Atrophic gastritis & 5 & $1,229 \pm 0,126$ & $1,159 \pm 0,016$ & $1,137 \pm 0,019$ & $1,299 \pm 0,196$ & $1,473 \pm 0,096$ & $1,167 \pm 0,047$ \\
MNU/300th day & Intestinal metaplasia & 2 & $1,529 \pm 0,038$ & $1,094 \pm 0,133$ & $1,176 \pm 0,008$ & $1,396 \pm 0,107$ & $1,771 \pm 0,142$ & $1,209 \pm 0,002$ \\
MNU/940th day & Gastric cancer & 1 & 2,050 & 1,363 & 1,495 & 2,612 & 3,812 & 1,538 \\
MNU/960th day & Gastric cancer & 1 & 2,003 & 1,333 & 1,498 & 2,764 & 3,768 & 1,644 \\
\hline
\end{tabular}

Table II. Mean and standard deviation of protein expression of BLK, FGR, FYN, LYN, SRC and YES in different clinical profiles of MNU-treated animal biopsies.

\begin{tabular}{lcccccccc}
\hline Treatment & Histology & $\begin{array}{c}\text { No. of } \\
\text { animals }\end{array}$ & $\begin{array}{c}B L K \\
\text { Mean } \pm \text { SD }\end{array}$ & $\begin{array}{c}F G R \\
\text { Mean } \pm \text { SD }\end{array}$ & $\begin{array}{c}F Y N \\
\text { Mean } \pm \text { SD }\end{array}$ & $\begin{array}{c}L Y N \\
\text { Mean } \pm \text { SD }\end{array}$ & $\begin{array}{c}\text { SRC } \\
\text { Mean } \pm \text { SD }\end{array}$ & $\begin{array}{c}Y E S \\
\text { Mean } \pm \text { SD }\end{array}$ \\
\hline Baseline & Normal mucosa & 6 & 1 & 1 & 1 & 1 & 1 & 1 \\
MNU/90th day & Non-atrophic gastritis & 6 & $1,211 \pm 0,263$ & $1,001 \pm 0,044$ & $0,980 \pm 0,101$ & $1,035 \pm 0,108$ & $1,045 \pm 0,072$ & $0,996 \pm 0,024$ \\
MNU/120th day & Atrophic gastritis & 5 & $1,063 \pm 0,030$ & $0,999 \pm 0,076$ & $1,086 \pm 0,046$ & $1,215 \pm 0,159$ & $1,294 \pm 0,147$ & $1,094 \pm 0,053$ \\
MNU/300th day & Intestinal metaplasia & 2 & $1,393 \pm 0,054$ & $1,177 \pm 0,007$ & $1,115 \pm 0,003$ & $1,312 \pm 0,253$ & $1,411 \pm 0,341$ & $1,163 \pm 0,033$ \\
MNU/940th day & Gastric cancer & 1 & 1,879 & 1,233 & 1,348 & 1,984 & 2,45 & 1,222 \\
MNU/960th day & Gastric cancer & 1 & 1,894 & 1,222 & 1,362 & 1,964 & 2,987 & 1,303 \\
\hline
\end{tabular}

in a model of intestinal gastric carcinogenesis generated by the treatment of Cebus apella, a New World non-human primate with $\mathrm{N}$-methyl nitrosourea (MNU).

\section{Materials and Methods}

We treated six Cebus apella, with N-methyl-nitrosourea (MNU) for about 2.5 years. All animals developed pre-neoplastic lesions. On the 90th day, all had non-atrophic gastritis. On the 110th day, an animal died of drug intoxication. On the 120th day, the remaining five animals had atrophic gastritis. On day 300, two surviving animals exhibited intestinal metaplasia in the gastric mucosa. On day 940 , the only animal that survived progressed to intestinal-type adenocarcinoma in the antral region of the stomach.

Real-time quantitative reverse transcription PCR (RT-qPCR) was performed to evaluate mRNA expression of the genes: $S c r, L Y N$, $B L K$, Yes, $F Y N, F G R$. RNA was reverse-transcribed using the HighCapacity cDNA Archive kit according to the manufacturer's protocol (Life Technologies, CA, USA). Complementary DNA was then amplified by RT-qPCR using TaqMan probes purchased as Assays-on-demand products for gene expression (Life Technologies) and a 7500 Fast Real-Time PCR instrument (Life Technologies). The GAPDH gene was selected as an internal control for RNA input and reverse-transcription efficiency. All RT-qPCRs were performed in triplicate for all target genes (SRC: Hs01082246_m1; LYN: Hs01015816_m1; BLK: Hs01017458_m1; Yes: Hs00736972_m1; FYN: Hs00176628_m1; FGR: Hs00961399_m1) and the internal control (GAPDH: NM_002046.3).
Protein expression was measured by western blotting. Protein samples $(25 \mu \mathrm{g})$ were separated by $12.5 \%$ homogeneous SDS-PAGE and electroblotted onto a PVDF membrane (Hybond-P, GE Healthcare, Chicago, IL, USA). The PVDF membrane was blocked with phosphate-buffered saline containing $0.1 \%$ Tween 20 , and $5 \%$ low fat milk and incubated overnight at $4^{\circ} \mathrm{C}$ with the corresponding primary antibodies anti-SRC, anti-LYN, anti-BLK, anti-Yes, antiFYB, anti-FGR and anti-ACTB (Life Technologies). After extensive washing, a peroxidase-conjugated secondary antibody was added for $1 \mathrm{~h}$ at room temperature. Immunoreactive bands were visualized using the western blotting Luminol reagent, and the images were acquired using an ImageQuant 350 digital image system (GE Healthcare, Uppsala, Sweden). ACTB was used as a loading reference control.

Ethics. In this study, the details of animal welfare and steps taken to ameliorate suffering were in accordance with the recommendations of the Weatherall report, "The use of non-human primates in research". This study was approved by the Ethics Committee of Universidade Federal do Pará (PARECER MED002-10).

Statistical analysis. ANOVA 2 test was used to compare changes in gene and protein expression, along with Tukey's multiple comparisons test $(p<0.05)$ using the Bioestat 5.0 program.

\section{Results}

mRNA levels of $B L K, F G R, F Y N, L Y N, S R C$ and $Y E S$ were, in the majority of cases, significantly higher in atrophic 
gastritis that in normal mucosa, $(p<0.01)$. In addition, the levels of $B L K$ gene mRNA were, statistically, significantly higher in non-atrophic gastritis than in normal mucosa $(p<0.05) . F Y N, L Y N$ and SRC mRNA levels were significantly higher in atrophic gastritis than in non-atrophic gastritis $(p<0.05)$.

Due to the reduced number of samples used, we did not include intestinal metaplasia and GC samples in the statistical comparison between the different stages of gastric carcinogenesis. However, a continuous increase in mRNA expression, mainly of $L Y N$ and $S R C$ was observed as nonatrophic gastritis progressed to GC. A 2.5 and 3.5-fold increase in the mRNA levels of $L Y N$ and $S R C$ was, respectively, was observed (Table I).

Statistical analysis of western blot data indicated that the protein levels of LYN, SRC and YES were significantly higher in atrophic gastritis samples than normal mucosa samples $(p<0.05)$ and only SRC and YES differed between the samples of non-atrophic gastritis and atrophic gastritis. However, progression from non-atrophic gastritis to gastric cancer a 2-fold and 3-fold increase in the protein levels of LYN and SRC, respectively, were observed (Table II). Other studies have described an elevated expression of mRNA and protein kinases that may play an important role in the invasion and metastasis of gastric tumors (13-15). In addition, blocking of c-Src inhibited the invasive and migratory capacity of gastric cancer cells (13-15).

In the present study we observed an increase in mRNA and protein expression in most of the proteins of the SRC family kinases analyzed and especially in the levels of LYN and SRC. Some works corroborate our findings where there is a high increase in the levels of c-Src expression in human gastric cancer (8), showing that these kinases are upregulated in most gastric cancers $(16,17)$. It has been shown that SRC and LYN kinases were up-regulated by approximately $50 \%$ in GC samples (14), further documenting the relation of the overexpression of SRC and GC $(13,16,18)$. However, this scenario changes with respect to FYN, where overexpression has been observed in several other cancers (14). In a similar study involving Cebus apella treated with MNU, it was observed that the expression of MYC mRNA increased during gastric carcinogenesis (19).

Our study highlights the upregulation of members of the SRC family kinases in gastric cancer. These results suggest that members of this family play a key role in tumor progression and metastasis and therefore may be a promising target for the treatment of gastric cancer.

\section{Conflicts of Interest}

The Authors declare no conflicts of interest regarding this study.

\section{Acknowledgements}

This study was supported by Conselho Nacional de Desenvolvimento Científico e Tecnológico (CNPq; grants \#471072/2012-5 and 402283/2013-9.

\section{References}

1 Jemal A, Bray F, Center MM, Ferlay J, Ward E and Forman D: Global cancer statistics. CA Cancer J Clin 61(2): 69-90, 2011.

$2 \mathrm{He} \mathrm{CZ}$ and Zhang KH: Serum protein and genetic tumor markers of gastric carcinoma. Asian Pac J Cancer Prev 14(6): 3437-3442, 2013.

3 Lin W, Kao HW, Robinson D, Kung HJ, Wu CW and Chen HC: Tyrosine kinases and gastric cancer. Oncogene 19(49): 56805689,2000 .

4 Takeshima E, Hamaguchi M, Watanabe T, Akiyama S, Kataoka M, Ohnishi Y, Xiao HY, Nagai Y and Takagi H: Aberrant elevation of tyrosine-specific phosphorylation in human gastric cancer cells. Cancer Res 82(12): 1428-1435, 1991

5 Marshall CJ: Specificity of receptor tyrosine kinase signaling: transient versus sustained extracellular signal-regulated kinase activation. Cell 80(2): 179-185, 1995.

6 Yeatman TJ: A renaissance for SRC. Nat Rev Cancer 4(6): 470480, 2004.

7 Summy JM and Gallick GE: Treatment for advanced tumors: SRC reclaims center stage. Clin Cancer Res 12(5): 1398-1401, 2006.

8 Okamoto W, Okamoto I, Yoshida T, Okamoto K, Takezawa K, Hatashita E, Yamada Y, Kuwata K, Arao T, Yanagihara K, Fukuoka M, Nishio K and Nakagawa K: Identification of c-Src as a potential therapeutic target for gastric cancer and of MET activation as a cause of resistance to c-Src inhibition. Mol Cancer Ther 9(5): 1188-1197, 2010.

9 Nam HJ, Im SA, Oh DY, Elvin P, Kim HP, Yoon YK, Min A, Song SH, Han SW, Kim TY and Bang YJ: Antitumor activity of saracatinib (AZD0530), a c-Src/Abl kinase inhibitor, alone or in combination with chemotherapeutic agents in gastric cancer. Mol Cancer Ther 12(1): 16-26, 2013.

$10 \mathrm{Xia} \mathrm{HJ}$ and Chen CS: Progress of non-human primate animal models of cancers. Dongwuxue Yanjiu 32(1): 70-80, 2011.

11 Takayama S, Thorgeirsson UP and Adamson RH: Chemical carcinogenesis studies in nonhuman primates. Proc Jpn Acad Ser B Phys Biol Sci 84(6): 176-188, 2008.

12 Leal MF, Calcagno DQ, Khayat AS, Silva TC, Muniz JA, Assumpção PP, de Arruda Cardoso Smith M and Burbano RR: hTERT and TP53 deregulation in intestinal-type gastric carcionogenesis in non-human primates. Clin Exp Med 13(3): 221-224, 2013

13 Yang Y, Bai ZG, Yin J, Wu GC and Zhang ZT: Role of c-Src activity in the regulation of gastric cancer cell migration. Oncol Rep 32(1): 45-49, 2014.

14 Mello AA, Leal MF, Rey JA, Pinto GR, Lamarão LM, Montenegro RC, Alves AP, Assumpção PP, Borges Bdo N, Smith MC and Burbano RR: Deregulated expression. Of SRC, LYN and CKB Kinases by DNA methylation and its potential role in gastric cancer invasiveness and metastasis. PLoS One 10(10): 113,2015

15 Kurashige J, Hasegawa T, Niida A, Sugimachi K, Deng N, Mima K, Uchi R, Sawada G, Takahashi Y, Eguchi H, Inomata M, Kitano S, Fukagawa T, Sasako M, Sasaki H, Sasaki S, Mori M, 
Yanagihara K, Baba H, Miyano S, Tan P and Mimori K: Integrated molecular profiling of human gastric cancer identifies DDR2 as a potential regulator of peritoneal dissemination. Sci Rep 6: 1-11, 2016.

16 Humar B, Fukuzawa R, Blair V, Dunbier A, More H, Charlton A, Yang HK, Kim WH, Reeve AE, Martin I and Guilford P: Destabilized adhesion in the gastric proliferative zone and $\mathrm{c}-\mathrm{Src}$ kinase activation mark the development of early diffuse gastric cancer. Cancer Res 67(6): 2480-2489, 2007.

17 Peng L, Ran YL, Hu H, Yu L, Liu Q, Zhou Z, Sun YM, Sun LC, Pan J, Sun LX, Zhao P and Yang ZH: Secreted LOXL2 is a novel therapeutic target that promotes gastric cancer metastasis via the Src/FAK pathway. Carcinogenesis 30(10): 1660-1669, 2009.
18 Masaki T, Shiratori Y, Okada H, Nishioka M, Taniguchi K, Hatanaka $\mathrm{Y}$ and Omata $\mathrm{M}$ : pp60c-src activation in gastric carcinoma: a preliminary study. Am J Gastroenterol 95(3): 837$838,2000$.

19 da Costa Jde F, Leal MF Silva TC, Andrade Junior EF, Rezende AP, Muniz JA, Lacreta Junior AC, Assumpção PP, Calcagno DQ, Demachki S, Rabenhorst SH, Smith Mde A and Burbano RR: Experimental gastric carcinogenesis in cebus apella nonhuman primates. PLoS One 6(7): 1-13, 2011.

Received September 17, 2018 Revised September 27, 2018 Accepted October 1, 2018 